\title{
Impact of Salt Stress on Germination and Growth on Chickpea (Cicer arietinum L.): A Review
}

\author{
Deva Jyotsna*, Ankhisatpathi, Om Swaroop, Navdeep Singh and C. Dinesh Kumar
}

School of Agriculture, Lovely Professional University, Phagwara, Punjab, India

*Corresponding author

\section{A B S T R A C T}

\begin{tabular}{|l|}
\hline Ke y w or d s \\
$\begin{array}{l}\text { Chickpea, Salinity, } \\
\text { Total yield, } \\
\text { Nitrogen fixation, } \\
\text { Nodule formation }\end{array}$ \\
\hline Article Info \\
\hline $\begin{array}{l}\text { Accepted: } \\
12 \text { October } 2020 \\
\text { Available Online: } \\
10 \text { November } 2020\end{array}$ \\
\hline
\end{tabular}

Chickpea (Cicer arietinum L.) is among those major pulse crop which is majorly grown along the semi-arid and arid regions across the world, most often on saline soils chickpea is highly sensitive to salinity and its growth is highly affected. The main aim of this study was to examine the affect on germination and early stages of growth in chickpea by different salt concentrations in solutions. So that to determine the safe degree of salinity that can be used for the crop cultivation. Salinized artificially rooting media with sodium chloride has been used to study the salt tolerance level in chickpea varieties $\mathrm{C}-44$ and $\mathrm{Pb}-91$. Thus, results stated that with increase in salinity level, there was gradual decline in seedling characters, germination, yield and yield components.

\section{Introduction}

Chickpea (Cicer arietinum L.), which is also known as Bengal gram or Garbanzo bean, is an Old-World pulse crop, and in the Fertile Crescent of the Near East, it was one of seven Neolithic founder crops (Lev-Yadun, Gopher \& Appo (2000)). Chickpea offers excellent grade protein, increases the input of combined $\mathrm{N} 2$ in soil and is most prominent crop of the Mediterranean region (Herridge et al., 1995). Among all the food legumes for world production, chickpea holds third position (FAO 2008) after beans (Phaseolus spp.) and field pea (Pisum sativum L.). The two different varieties of chickpea used for cultivation are: Kabuli (macrosperma) and Desi (microsperma). Desi type of chickpea variety posses pink flowers, coloured and thick seed coat, and ananthocyanin pigmentation on stems. Whereas The Kabuli type of chickpea possess white flowers, seeds with white or beige colour, seed shape like a ram's head, seed coat is thin and consists a smooth surface and it lacks anthocyanin pigmentation on stems (Moreno and Cubero (1978).

$140 \mathrm{~kg} \mathrm{~N}$ ha-1 year-1 is fixed by chickpea and has a key role in sustaining soil fertility. it also has great value in human food as well as animal feed (Rupela, 1987). Thus, this crop 
requires very low-input, and $70 \%$ of its nitrogen demand is derived by symbiotic N2 fixation and other cereal crops are benefited (Siddique et al., 2005). The major stress factors of this crop is salinity that leads to limitation in production of crop caused by osmotic and specific ion effects in most of the semi-arid as well as arid regions across the world (Bernstein, 1975).In many regions of the world Salinity of soil is one of the major factor of environmental constraints in agriculture. Salt stress majorly affects the growth and symbiotic performance of nodulated legumes (Boyer, 1982; Serrano and Gaxiola, 1994). Especially at reproductive stage of growth chickpea is highly susceptible to salt stress (Kotula et al., 2015), first the roots of crop suffers (Tejera et al., 2006) which further results in lesser productivity (Singla and Garg, 2005; Sohrabi et al., 2008). Germination and early stages of chickpea are mainly affected by soil salinity (Khan et al., 2013).

\section{Effect of salt stress on plant growth}

Increased level of concentration of $\mathrm{NaCl}$ in soil possesses an unfavourable effect on length of plumule and radical which leads to suppress growth of radical and plumule. The growth medium when contain any unexpected salt concentration can lead to reduction of absorption of water due to osmotic potential lessening and affect cell division (Ashraf and Harris, 2005). Negative effect in the length of plumule and radical is seen in this salt experiment. As per, (Kausar et al., 2012) salinity effect retards the length of plumule and radical and other affects are may be due to disruption in uptake of nutrients, ion toxicity (Akhter et al., 2012), osmotic effects of salinity (Ashraf and Harris, 2005), water absorption (Ashraf and Sarwar, 2002), which results in reduction of plant hormones required for growth and biosynthesis of enzymes (Bor et al., 2003). As $\mathrm{NaCl}$ concentration level is increased, the length of radicle and plumule are decreased in all land races. These results are stated in many researches (Farsiani and Ghobadi, 2009; Jajarmi, 2009).

\section{Germination}

At high Salinity levels the germination results were suppressed whereas good germination was seen in control and other salinity levels. Gram variety $\mathrm{Pb}-91$ indicated high percentage of germination when compared with C-44 variety. With increase in salinity level, germination percentage was decreased (Mrumaker and Chavan, 1987).

\section{Seedling growth}

All salinity levels suppressed the length of plumule and radical when compared with control. At lower salinity level, fresh weight of seedling was observed same as in control. Both $\mathrm{Pb}-91$ and $\mathrm{C}-44$ varieties resulted decrease in fresh weight of seedlings (Hanks et al., 1977). Similarly when salinity levels were increased beyond extreme had no affect on fresh weight of seedling. Salinity level when compared to control has majorly affected dry weight of seedling. When compared high saline medium to control, it showed gradual decrease in seedling's dry weight (Dua and Sharma, 1995). In control and low salinity levels, the growth of radical and plumule lengths and dry and fresh weights were observed finest, while at high saline treatments the growth resulted poor in both the varieties. Intermediate growth of seedlings was observed in moderately saline treatments. Accretion of toxic ions in radical and plumule seedlings and reduction of water availability physiologically with increased suction of solute from salt medium leads to decline seedling's fresh weight (Gill and Dutt, 1983). 


\section{Plant growth and yield}

$\mathrm{Pb}-91$ gram variety possessed longer shoot and root length than that of C-44. In high saline treatments the root length was short and the longest root length was observed in control. The dry weight of shoot was progressively decreased with increase in the levels of salinity. The total yield produced was more by $\mathrm{Pb}-91$ variety and the lesser total yield was produced by $\mathrm{C}-44$ variety.

The count of flowers per plant is reduced and delay in flowering was observed in these varieties with increase in salinity levels (Datta et al., 1981; Dhingra and Varghese, 1993). Total yield of these varieties gradually decreased due to salinity (Manchandra and Sharma, 1990). Adverse effects were seen on both the varieties but C-44 showed more reduction than $\mathrm{Pb}-91$. Thus, both these varieties resulted to be salt sensitive. But when compared with $\mathrm{Pb}-91, \mathrm{C}-44$ was more salt sensitive based on their growth parameter.

\section{Nitrogen fixation}

Adverse effect of salinity on $\mathrm{N} 2$ fixation in plant legumes, reduced the supply of photosynthate to nodules (Bekki et al., 1987; Georgiev and Atkins, 1993). Oxygendiffusion barrier alteration (Serraj et al., 1994) and reduction of respiratory substrate supply to the bacteroids (Delgado et al.1993, 1994) have been explained by advancement of several hypothesis.

The bacterial symbiosis with chickpea roots was suppressed in presence of salinity in the soil. Salinity of soil also leads to decrease the regulation of biological procedure in improvement of crop growth (Zurayk et al., 2008). The harmful effects on nodule initiation by salinity lead to reduction in formation of nodules by the sensitive cultivars. Invigoration in nodule count and dry mass of nodule due to salinity vary from the records of (Elshiekh and Wood (1990), Sheokand et al., (1995) and decrease in nodulation under salt stress was observed by most of the other workers. But, current records estimated by Soussi et al., (1999) and Cordovilla et al., (1999) have indicated a gush in growth of nodule that gradually increased the nodule's dry mass.

\section{Physiological changes in growth of chickpea}

Chickpea raised in $\mathrm{NaCl}(100 \mathrm{~mm})$ resulted in decrease in concentration of photosynthetic pigments (Datta and Sharma 1990; Beltagi 2008), therefore $60 \%$ reduction in photosynthesis was resulted (Murumkar and Chavan 1993). Due to the effect on chlorophyll-fluorescence by salinity, genotypes have also shown to differ (Epitalawage et al., 2003). Senescence in chickpea is increased due to salinity (Katerji et al., 2001) and leads to induction of ethylene production in root nodules (Kukreja et al., 2005; Nandwal et al., 2007).

In conclusion thus, germination as well as early stages of growth are highly effected by salinity in soil. Germination stage is very highly susceptible to salinity. Chickpea can be cultivated in marginally saline environment $(0.61 \pm 0.04 \mathrm{~g} / \mathrm{L}$ range of $\mathrm{NaCl}$ concentration), without any considerable decrease on its growth and development. When the crop is exposed to higher degrees of salinity it results in strong suppression.

\section{References}

Akhtar MF, Hussain MY, Ashraf TM, Qureshi T, Akhter J, et al., (2012) Influence of salinity on nitrogen transformations in soil. Soil Sci Plant Analy 43: 1674-1683.

Ashraf MY, Sarwar G (2002) Salt tolerance 
potential in some members of Brassicaceae. Plysiological studies on water relations and mineral contents. In: Prospects for Saline Agriculture. Ahmad R, Malik KA (Eds). Kluwer Academic Publishers Springer, the Netherlands. pp. 237-245.

Ashraf M, Harris PJ (2005) Abiotic stresses: Plant resistance through breeding and molecular approaches. Food Products Press.

Bekki K, Trinchant JC, Rigaut J. 1987. Nitrogen fixation by Medicago sativa nodules and bacteroids under sodium chloride stress. Physiologia Plantarum 71, 61-7.

Bernstein, L., 1975. Effects of salinity and sodicity on plant growth. Ann. Rev. Phytopathol., 13: 295-312.

Bor M, Ozdemir F, Turkan I (2003) The effect of salt stress on lipid peroxidation and antioxidants in leaves of sugar beet (Beta vulgaris L.) and wild beet (Beta maritima L.). J Plant Sci 164: 77-84.

Boyer JS. 1982. Plant productivity and environment. Science 218, 443-448. Serrano R, Gaxiola R. 1994. Microbial models and salt stress tolerance in plant. Critical Reviews in Plant Science 13, 121-138.

Cordovilla MDP, Ligero F, Lluch C (1999) Effect of salinity on growth, nodulation and nitrogen assimilation in nodules of faba bean (Vicia faba L.). Applied Soil Eco. 11:1-7.

Datta, K.S., J. Dayal and C.L. Goswami, 1981. Effect of salinity on growth and yield attributes of Chickpea (Cicer arietinum L.). Ann. Biol., 36: 47-53.

Datta K.S. and Sharma K.D. (1990) Effect of chloride and sulphate types of salinity on characteristics of chlorophyll content, photosynthesis and respiration chickpea (Cicer arietinum L.). Biologia Plantarum (Prague) 32, 391-395.

Delgado MJ, Garrido JM, Ligero F, Lluch C.
1993. Nitrogen fixation and carbon metabolism by nodules and bacteroids of pea plants under sodium chloride stress. Physiologia Plantarum 89, 8249.

Dhingra, H.R. and T.M. Varghese, 1993. Flowering and male reproductive functions of chickpea (Cicer arietinum L.) genotypes as affected by salinity. Biol. Planta., 35: 447-452.

Dua, R.P. and P.C. Sharma, 1995.Salinity tolerance of Kabuli and Desi chickpea genotypes. Int. Chickpea Pigeon pea Newslett., 2: 19-22.

Elsheikh EAE, Wood M (1990) Effect of salinity on growth, nodulation and nitrogen yield of chickpea (Cicer arietinum L.). J. Exp. Bot. 41:12631269.

Epitalawage N., Eggenberg P. and Strasser R.J. (2003) Use of fast chlorophyll a fluorescence technique in detecting drought and salinity tolerant chickpea (Cicer arietinum L) varieties. Archives Des Sciences 56, 79-93.

Farsiani A, Ghobadi ME (2009) Effects of PEG and $\mathrm{NaCl}$ stress on two cultivars of corn (Zea mays L.) at germination and early seedling stages. World AcadSci Eng. Tech 57: 382-385.

Georgiev GI, Atkins CA. 1993. Effects of salinity on $\mathrm{N}_{2}$ fixation, nitrogen metabolism and export and diffusive conductance of cowpea root nodules. Symbiosis 15, 239-55.

Gill, K.S. and S.K. Dutt, 1983. Nature of salt injury at germination stage in paddy.Curr. Sci., 52: 1020-1022.

Hanks, R.J., T.E. Sullivan and V.E. Hunsaker, 1977. Corn and Alfalfa production as influenced by irrigation and salinity. Soil Sci. Soc. Am. J., 41: 606-610.

Herridge DF, Marcellos H, Felton WL, Turner GL. 1995. Chickpea increases soil-N fertility in cereal systems through nitrate sparing and N2 fixation. Soil 
Biology and Biochemistry 27,545-51.

Jajarmi V (2009) Effect of water stress on germination indices in seven wheat cultivar. World Acad Sci Eng Tech 49: 105-106.

Katerji N., van Hoorn J.W., Hamdy A., Mastrorilli M., Oweis T. \&Malhotra R.S. (2001) Response to soil salinity of two chickpea varieties differing in drought tolerance. Agricultural Water Management 50, 83-96.

Kausar A, Ashraf MF, Ali I, Niaz M, Abbass Q (2012) Evaluation of sorghum varieties/lines for salt tolerance using physiological indices as screening tool. Pak J Bot 44: 47-52.

Khan S, Iqbal J, Saeed M (2013) Comparative study of grain yield and biochemical traits of different rice varieties grown under saline and normal conditions. J Anim Plant Sci 23: 575-588.

Kotula, L., Khan, H. A., Quealy, J., Tumer, N. C., Vadez (2015). Salt sensitivity in chickpea (Cicer arientinum L.): Ions in reproductive tissues and yield components in contrasting genotypes. Plant, Cell and Environment, 38(8), 1565-1577.

Kukreja S., Nandwal A.S., Kumar N., Sharma S.K., Sharma S.K., Unvi V. \& Sharma P.K. (2005) Plant water status, $\mathrm{H} 2 \mathrm{O} 2$ scavenging enzymes, ethylene evolution and membrane integrity of Cicer arietinum roots as affected by salinity. Biologia Plantarum 49, 305-308.

Lev-Yadun S, Gopher A and Abbo S (2000) The cradle of agriculture. Science 288, 1062-1063.

Manchandra, H. and S. Sharma, 1990. Influence of different chloride: Sulphate ratio on yield of chickpea. (Cicer arietinum L.) at comparable salinity levels. Indian J. Agric. Sci., 60: 553555.

Moreno M \& Cubero JI (1978) Variation in Cicer arietinum L. Euphytica 27, 465-
485.

Mrumaker, C.V. and P.D. Chavan, 1987. Salinity induced biochemical changes during germination of chickpea. ActicaAgronmic-Hungarica, 36: 39-43.

Murumkar C.V. and Chavan P.D. (1993) Alterations in photosynthetic carbon metabolism of chickpea (Cicer arietinum L) due to imposed nacl salinity. Agrochimica 37, 26-32.

Nandwal A.S., KukrejaS., Kumar N., Sharma P.K., Jain M., Mann A. \& Singh S. (2007) Plant water, status, ethylene evolution, N-2fixing efficiency, antioxidant activity and lipid peroxidation in Cicer arietinum $\mathrm{L}$. nodules as affected by short-term salinization and desalinization. Journal of Plant Physiology 164, 1161- 1169.

Rupela O. (1987) Nodulation and nitrogen fixation in chickpea. In The Chickpea (eds M. Saxena and K.B. Singh), pp. 191-206. CAB International, Wallingford, UK.

Serraj R, Roy G, Drevon JJ. 1994. Salt stress induces a decrease in the oxygen uptake of soybean nodules and in their permeability to oxygen diffusion. Physiologial Plantarum 91, 161-8.

Sheokand S, Dhandi S, Swaraj K (1995) Studies on nodule functioning and hydrogen peroxide scavenging enzymes under salt stress in chickpea nodules. Plant Physiol. 33:561-566.

Siddique K.H., Johansen C., Kumarrao J.V.D.K. and Ali M. (2005) Legumes in sustainable cropping systems. Paper presented at The Fourth International Food Legumes Research Conference, New Delhi - India.

Singla, R., and Garg, N. (2005). Influence of salinity on growth and yield attributes in chickpea cultivars. Turkish Journal of Agriculture and Forestry, 29(4), 231235.

Sohrabi, Y., Heidari, G., and Esmailpoor, B. 
(2008).Effect of salinity on growth and yield of Desi and Kabuli chickpea cultivars. Pakistan Journal of Biological Sciences, 11(4), 664-667.

Soussi M, Ocana A, Lluch C (1998) Effect of salt stress on growth, photosynthesis and nitrogen fixation in chickpea (Cicer arietinum L.). J. Exp. Bot. 49:1329-37.

Soussi M, Lluch C, Ocana A (1999) Comparative study of nitrogen fixation and carbon metabolism in two chickpea (Cicer arietinum L.) cultivars under salt stress. J. Exp. Bot. 50:1701-1708.
Tejra, N. A., Soussi, M., and Lluch, C. (2006). Physiological and nutritional indicators of tolerance to salinity in chickpea plants growing under symbolic conditions. Environmental and Experimental Botany, 58, 17-24.

Zurayk, R, Adlan, M, Baalbaki, R, and Saxena, M. C. (1998). Interactive effects of salinity and biological nitrogen fixation on chickpea (Cicer arietinum L.) growth. Journal of Agronomy and Crop Science, 180(4), 249-258.

\section{How to cite this article:}

Deva Jyotsna, Ankhisatpathi, Om Swaroop, Navdeep Singh and Dinesh Kumar, C. 2020. Impact of Salt Stress on Germination and Growth on Chickpea (Cicer arietinum L.): A Review. Int.J.Curr.Microbiol.App.Sci. 9(11): 1416-1421. doi: https://doi.org/10.20546/ijcmas.2020.911.166 